\title{
Karyotype variability in eight species of the subfamilies Loricariinae and Ancistrinae (Teleostei, Siluriformes, Loricariidae)
}

\author{
Anderson Luís Alves, Claudio Oliveira* and Fausto Foresti \\ Departamento de Morfologia, Instituto de Biociências, Universidade Estadual Paulista, 18618-000, Botucatu, SP, Brazil.
}

\begin{abstract}
Loricariidae is one of the largest fish families of the world, with about 650 species separated into six subfamilies. To date, cytogenetic data on only 56 species of this family are available. In the present study, the karyotypes of three Ancistrinae species and five Loricariinae species were studied. The lowest diploid number, $2 n=38$, was observed in Ancistrus n.sp. 1 (Ancistrinae) and the highest diploid number, $2 n=70$, was observed in Rineloricaria n.sp. (Loricariinae). The nucleolar organizer regions (NORs) were seen at a terminal position in six species and at an interstitial position in two. The karyotypic analysis of Loricariinae and Ancistrinae species revealed that these groups exhibit a large diversity of diploid numbers, suggesting the occurrence of intense karyotypic evolution during their evolutionary history.
\end{abstract}

Key words: Chromosome, karyotypic variability, NOR banding, Loricariidae, Siluriformes.

\section{INTRODUCTION}

The family Loricariidae, one of the largest fish families of the world, has about 650 species distributed in the Neotropical region (ISBRÜCKER 1980; NELSON 1994; FERRARIS 1998). The family is divided into six subfamilies: Hypostominae, Ancistrinae, Loricariinae, Hypoptopomatinae, Neoplecostominae, and Lithogeninae (SCHAEFER 1987 ) and in spite of numerous studies recently developed (ARMBRUSTER et al. 2000; ARMBRUSTER 2002); the identification of many species groups is still a very difficult task, which show that further studies, taxonomic reviews and species descriptions are necessary.

Cytogenetic studies were conducted in only about 56 species of Loricariidae (OLIVEIRA and GoszTONYI 2000). In this family, diploid num-

\footnotetext{
* Corresponding author: fax +55 14 6821-3744; e-mail: claudio@ibb.unesp.br
}

bers range from $2 n=36$ in Rineloricaria latirostris (GiUliano-CAETANO 1998) to $2 n=80$ in Hypostomus sp. (ARTONI and BerTOllo 1996). Most of the cytogenetic studies so far conducted focused on species of the subfamily Hypostominae which exhibits the greatest diversity of diploid numbers, from $2 n=52$ to $2 n=80$ chromosomes (Alves 2000). Among the karyotyped Ancistrinae species, diploid numbers range from $2 n=48$ to $2 n=52$ (Table 1) and, in Loricariinae, they range from $2 n=36$ to $2 n=74$ (Table 1 ). In contrast to these subfamilies that show a great variation in diploid number and karyotype, fish of the subfamilies Hypoptopomatinae and Neoplecostominae are characterized by the presence of $2 n=54$ chromosomes in almost all species (Alves 2000). In the present study, the karyotypes of three Ancistrinae species and five Loricariinae species were investigated with the main purpose of characterizing these species and analyzing the chromosomal relationships between these subfamilies. 


\section{MATERIAL AND METHODS}

Cytogenetic analyses were performed on chromosome preparations from three Ancistrinae species and five Loricariinae species, collected from streams of five Brazilian hydrographic basins (Table 1). The specimens were studied by taxonomists that provided the species identification, when possible. Two species of Ancistrus (here identified as Ancistrus n.sp. 1 and Ancistrus n.sp.2) and one species of Rineloricaria (here identified as Rineloricaria n.sp) were not named because they are new to science. The description of these species will be done elsewhere. The fish were deposited in the fish collection of Laboratório de Biologia de Peixes (LBP), UNESP, Botucatu, São Paulo, Brazil or in the Laboratório de Ictiologia, Museu de Ciências e Tecnologia, PUCRS (MCP), Porto Alegre, Brazil.

Chromosome preparations were obtained from gill and kidney tissues using the technique described by FORESTI et al. (1993). Silver-staining of the nucleolar organizer regions was performed according to the technique proposed by HOWELL and BLACK (1980). Chromosome morphology was determined on the basis of arm ratio as proposed by LEVAN et al. (1964) and chromosomes were classified as metacentric (M), submetacentric (SM), subtelocentric (ST) and acrocentric (A).

\section{RESULTS}

Our results showed that Ancistrus n.sp. 1 exhibited $2 n=38$ chromosomes ( 30 M/SM, 8 ST) and one metacentric pair with interstitial NORs in the short arms (Fig. 1a). Ancistrus n.sp. 2 displayed $2 n=52$ chromosomes ( $32 \mathrm{M} / \mathrm{SM}, 20$ ST/A) and one subtelocentric pair with terminal NORs in the short arms (Fig. 1b). Ancistrus multispinnis had $2 n=52$ chromosomes $(28 \mathrm{M} / \mathrm{SM}, 24$ ST/A) and one subtelocentric pair with terminal NORs in the short arms (Fig. 1c).

Among Loricariinae species, Harttia loricariformis had $2 n=52$ chromosomes $(32 \mathrm{M} / \mathrm{SM}, 20$ $\mathrm{ST} / \mathrm{A}$ ) and one acrocentric pair with interstitial NORs in the long arms (Fig. 2a); Harttia kronei had $2 n=58$ chromosomes (40 M/SM, $18 \mathrm{ST} / \mathrm{A})$

Table 1 - A summary of the cytogenetic data available on the subfamilies Loricariinae and Ancistrinae.

\begin{tabular}{|c|c|c|c|c|}
\hline Species & Locality & $2 n$ & Karyotypic formulae & Reference \\
\hline \multicolumn{5}{|l|}{ Ancistrinae } \\
\hline Ancistrus n.sp. 1 & São Francisco river, Acre, Brazil & 38 & 30M/SM, 8ST & Present study \\
\hline Ancistrus sp. & Iguaçú river, Paraná, Brazil & 48 & 18M, 14SM, 12ST, 4A & LARA and JÚLIO JR. (1994) \\
\hline Ancistrus sp. & Alto Alegre river, Paraná, Brazil & 50 & $12 \mathrm{M}, 14 \mathrm{SM}, 14 \mathrm{~T}, 10 \mathrm{~A}$ & TCHAICKA and MARGARIDO (1999) \\
\hline Ancistrus n.sp. 2 & Betari river, São Paulo, Brazil & 52 & 32M/SM, 20ST/A & Present study \\
\hline Ancistrus multispinnis & Itapocu river, Santa Catarina, Brazil & 52 & 28M/SM, 24ST/A & Present study \\
\hline Megalancistrus aculeatus & Paraná river, Paraná, Brazil & 52 & 26M, 26SM & LARA and JÚLIO JR. (1994) \\
\hline Hemiancistrus sp. & Araguaia river, Mato Grosso, Brazil & 52 & 20M, 20SM, 8ST, 4A & ARTONI (1996) \\
\hline Panaque cf. nigrolineatus & Araguaia river, Mato Grosso, Brazil & 52 & 26M, 20SM, 6ST & ARTONI (1996) \\
\hline \multicolumn{5}{|l|}{ Loricariinae } \\
\hline Harttia sp. & Itabapoana river, Minas Gerais, Brazil & 56 & $14 \mathrm{SM}, 42 \mathrm{~A}$ & CARNEIRO et al. (1998) \\
\hline Harttia kronei & Betari river, São Paulo, Brazil & 58 & 40M/SM, 18ST & Present study \\
\hline Harttia loricariformis & Grande river, São Paulo, Brazil & 52 & 32M/SM, 20ST/A & Present study \\
\hline Loricaria carinata & Paraná river, Argentina & 64 & - & RONCATI et al. (1999) \\
\hline Loricaria macrodon & - & 58 & $18 \mathrm{M}, 2 \mathrm{SM}, 38 \mathrm{~A}$ & MiCHELLE et al. (1977) \\
\hline Loricaria parva & - & 48 & - & GYLDENHOLM and SCHEEL (1971) \\
\hline Loricaria prolixa & Paraná river, Paraná, Brazil & 62 & 20M, 4SM, 38A & SCAVONE and JÚlIO JR. (1995) \\
\hline Loricaria sp. & Paraná river, Paraná, Brazil & 64 & 10M, 6SM, 4ST, 44A & SCAVONE and Júlio JR. (1995) \\
\hline Loricaria sp. & Solimões river, Amazonas, Brazil & 62 & - & DELLA-Rosa et al. (1980) \\
\hline Loricaria sp. & Jari river, Pará, Brazil & 52 & - & OLIVEIRA et al. (1998) \\
\hline Loricariichtbys sp. & Paraná river, Argentina & 54 & 6M, 26SM, 4ST, 18A & FENOCCHIO (1993) \\
\hline Loricariichthys sp. & Itabapoana river, Minas Gerais, Brazil & 54 & $28 \mathrm{M}, 26 \mathrm{~A}$ & CARNEIRO et al. (1998) \\
\hline L. platymetopom & Paraná river, Paraná, Brazil & 54 & 7M, 20SM, 4ST, 23A & SCAVONE (1993) \\
\hline L. platymetopom & Paraná river, Argentina & 54 & - & RONCATI et al. (1999) \\
\hline L. maculata & Paraná river, Argentina & 56 & - & RONCATI et al. (1999) \\
\hline Rineloricaria latirostris & Passa-Cinco river, São Paulo, Brazil & $44-47$ & - & GIULIANO-CAETANO (1998) \\
\hline R. latirostris & Mogi-Guaçu river, São Paulo, Brazil & $36-40$ & - & GIULIANO-CAETANO (1998) \\
\hline R. latirostris & Três Bocas river, Paraná, Brazil & $43-48$ & - & GIULIANO-CAETANO (1998) \\
\hline R. pentamaculata & Keller river, Paraná, Brazil & 56 & 8M/SM, 48ST/A & GiULIANO-CAETANO et al. (1999) \\
\hline R. kronei & Itapocu river, Santa Catarina, Brazil & 64 & 6M/SM, 58ST/A & Present study \\
\hline R. cadeae & Guaíba river, Rio Grande do Sul, Brazil & 66 & 2M, 64ST/A & Present study \\
\hline Rineloricaria n.sp. & Betari river, São Paulo, Brazil & 70 & 2SM, 68A & Present study \\
\hline Sturisoma cf. nigrirostrum & Araguaia river, Mato Grosso, Brazil & 74 & 20M, 18SM, 18ST/A & ARTONI (1996) \\
\hline
\end{tabular}


and one submetacentric pair with terminal NORs in the short arms (Fig. 2b); Rineloricaria kronei had $2 n=64$ (6 M/SM, 58 ST/A) and one subtelocentric pair with terminal NORs in the short arms presenting a large size polymorphism (Fig. 3a); Rineloricaria cadeae had $2 n=66$ chromosomes (2 M, 64 ST/A) and one subtelocentric pair with terminal NORs in the short arms (Fig. 3b); and Rineloricaria n.sp. had $2 n=70$ chromosomes (2 SM, $68 \mathrm{~A}$ ) and one submetacentric pair with terminal NORs in the short arms (Fig. 3c).

\section{DISCUSSION}

The subfamily Ancistrinae is believed to be a monophyletic group (SCHAEFER 1987; DE PINNA 1998). Although this subfamily has about 190 species (ISBRÜCKER 1980), it is the Loricariidae subfamily that has the lowest number of species karyotyped (Table 1). The results obtained in the present study and those described in the literature show that $2 n=52$ chromosomes is a common characteristic in the group, being present in two species of Ancistrus and in three species of other genera (Table 1). Among the Ancistrinae species analyzed, most chromosomes are metacentric and submetacentric, as observed in most Loricariidae species (ARTONi and Bertollo 1996; Alves 2000).

The occurrence of a single chromosome pair with terminal NORs, observed in the majority of the Ancistrinae species, is also a common characteristic in Loricariidae (ARTONI and BERTOLLO 1996; ALVES 2000). In the present study, the species Ancistrus n.sp. 1 showed the most differentiated karyotype as it presents one of the lowest diploid number found in the family Loricariidae $(2 n=38)$ and interstitial NORs. To our knowledge, this is the first time that this characteristic is described in members of the subfamily Ancistrinae.

In Ancistrinae species, pericentric and paracentric inversions were probably the main chromosome rearrangements involved in the process of karyotypic evolution. This resulted in the different karyotypic formulae found in the different species. Moreover, centric fusions might have occurred and thus be responsible for the reduced

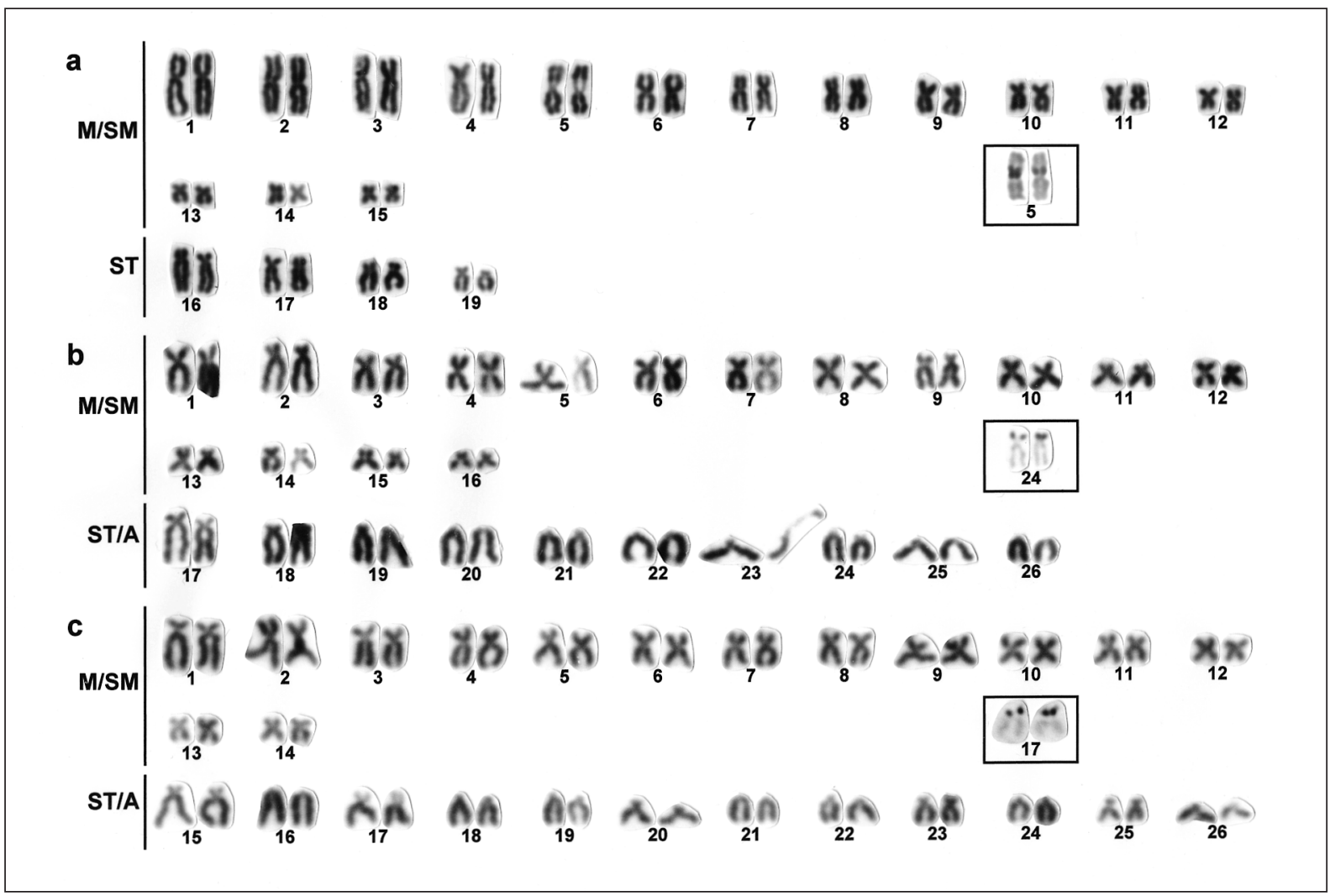

Fig. 1 - Giemsa stained karyotypes of fish from the subfamily Ancistrinae. (a) Ancistrus n.sp. 1 with $2 n=38$ chromosomes; (b) Ancistrus n.sp. 2 with $2 n=52$ chromosomes; (c) Ancistrus multispinnis with $2 n=52$ chromosomes. In the insets, the NORbearing pairs. 
diploid number found in some species such as Ancistrus n.sp. $1(2 n=38$, present study) and Ancistrus sp. (2n=48, LARA and JÚLIO JR. 1994) (Table 1). Therefore, the results obtained suggest that the species of the subfamily Ancistrinae had a divergent karyotypic evolution.

In spite of recent taxonomic studies in the subfamily Ancistrinae (e.g. ARMBRUSTER 2002), many taxonomic problems are still present, which make species identification a very difficult task. Thus, further studies are necessary for a better understanding of the karyotypic diversity of this subfamily as well as the relationship pattern between the members of this group.

The subfamily Loricariinae has been considered a well defined monophyletic group, the sister-group of the subfamilies Ancistrinae+Hypostominae (SCHAEFER 1987; De PinNA 1998). With about 200 species this is the largest Loricariidae subfamily in species number. Although cytogenetic descriptions are restricted to the karyotypes of five genera, they show a great karyotypic complexity (Table 1 ). In the present study, diploid number varied from $2 n=52$ in Harttia loricariformis to $2 n=70$ in Rineloricaria n.sp., these numbers are within the range observed in the subfamily Loricariinae (Table 1).

The only Harttia species cytogenetically studied so far exhibit $2 n=56$ chromosomes (Table 1 ).
The diploid numbers found in Harttia loricariformis $(2 n=52)$ and Harttia kronei $(2 n=58)$, suggest that the species in this genus have a high karyotypic variability. In the two species analyzed, most chromosomes were metacentric and submetacentric but, in Harttia sp. most chromosomes were acrocentric (Table 1). These results suggest that chromosome rearrangements occurred in the evolutionary history of this group and changed diploid number as well as chromosomal structure. This assumption is supported by the fact that, in Harttia kronei, NORs were at a terminal position and at an interstitial position in Harttia loricariformis.

Two Rineloricaria species had their karyotype described: Rineloricaria pentamaculata, with $2 n=56$ chromosomes (GIULIANO-CAETANO et al. 1999) and several local samples of Rineloricaria latirostris, whose diploid numbers ranged from $2 n=36$ to $2 n=48$ (GIULIANO-CAETANO 1998). In the present study, Rineloricaria n.sp. exhibited the higher diploid number in the genus, $2 n=70$, Rineloricaria cadeae showed $2 n=66$ and Rineloricaria kronei had $2 n=64$ chromosomes. Moreover, in the three species analyzed the karyotypes were different from those of $R$. pentamaculata and $R$. latirostris due the presence of a higher number of acrocentric chromosomes, mainly in Rineloricaria n.sp. $(2 n=70)$. The difference in diploid

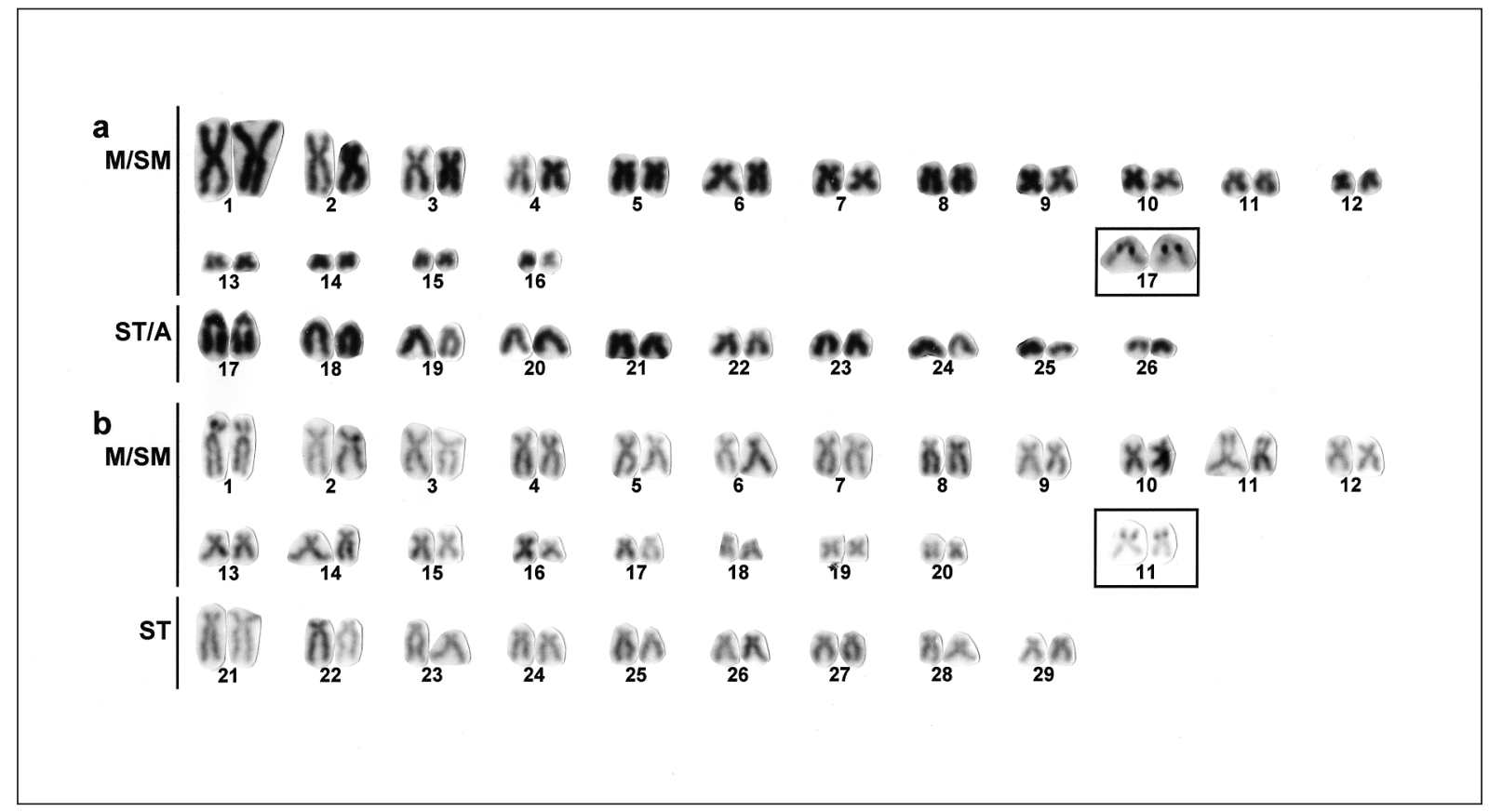

Fig. 2 - Giemsa stained karyotypes of fish from the subfamily Loricariinae. (a) Harttia loricariformis with $2 n=52$ chromosomes; (b) Harttia krone $i$ with $2 n=58$ chromosomes. In the insets, the NOR-bearing pairs. 
number probably indicates the presence of several natural groups or a high rate of karyotypic evolution in the genus Rineloricaria.

The high diploid number observed in some Loricariinae species is accompanied by a high number of acrocentric chromosomes (Table 1), suggesting the occurrence of centric fissions. The presence of terminal NORs in the short arms is a conservative characteristic seen in the three species of Rineloricaria studied. Additionally, Rineloricaria species exhibited evident NOR size polymorphisms, specially in $R$. kronei.

The presence of terminal NORs is probably an ancestral characteristic in the order Siluriformes (Oliveira and GoszTONYi 2000) and a common characteristic in Loricariidae species (Alves 2000). To our knowledge, this is the first time that interstitial NORs are reported in Ancistrus n.sp. 1 (Ancistrinae) and Harttia loricariformis (Loricariinae). However, this pheno- type is very common in Neoplecostominae and Hypoptopomatinae (ALVES 2000) and has also been described in some Hypostominae species (ARTONi and BERTOLlo 1996). Considering the high frequency of interstitial NORs in Loricariidae and the presence of interstitial NORs in some related groups such as Trichomycteridae and Callichthyidae (OLIVEIRA and GOSZTONYI 2000), it is possible to suggest that the presence of interstitial NORs is a primitive characteristic in Loricariidae.

The size polymorphism observed in the NORs, as evidenced in Rineloricaria kronei, is generated by unequal crossing-over or gene duplication, very common in Neotropical fish (FORESTI et al. 1981; AlMEIDA-TOLEDO et al. 2000), and already described in several Loricariidae species (ANDREATA et al. 1994; ARTONI and Bertollo 1996; Giuliano-Caetano 1998; ALVES 2000).

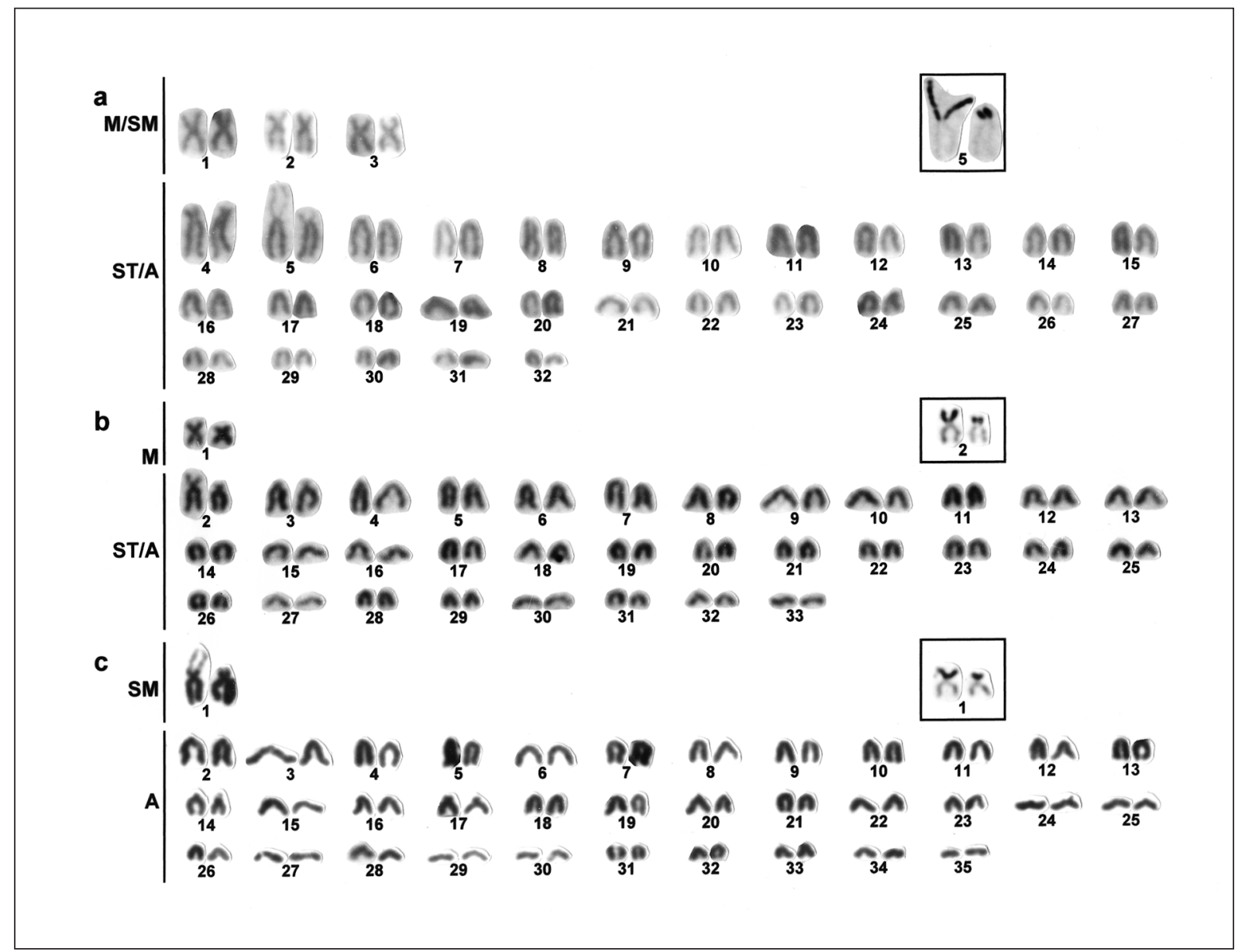

Fig. 3 - Giemsa stained karyotypes of fish from the subfamily Loricariinae. (a) Rineloricaria kronei with $2 n=64$ chromosomes; (b) Rineloricaria cadeae with $2 n=66$ chromosomes; (c) Rineloricaria n.sp. with $2 n=70$ chromosomes. In the insets, the NORbearing pairs. 
The high karyotypic complexity observed in the subfamilies Ancistrinae and Loricariinae, hindered the proposition of relationship pattern between their components. Further studies on different species using other kind of information such as morphological and molecular data, will be very useful to a better understanding of the karyotypic evolution in the family Loricariidae.

Acknowledgments - The authors are grateful to Renato Devidé for technical assistance, and to Dr. Roberto E. Reis, to Dr. Osvaldo T. Oyakawa, and to MsC. Edson H. L. Pereira for the taxonomic identification of the species. Funds supporting this study were provided by FAPESP.

\section{REFERENCES}

Almeida-Toledo L.F., Foresti F. and ToledoFILHO S.A., 2000 - Karyotypic evolution in Neotropical freshwater. Chromosomes Today, 13: 169-182.

ALVES A.L., 2000 - Análise da evolução dos gêneros da subfamília Hemipsilichtbiinae (Ostariopbysi, Siluriformes, Loricariidae) com base em caracteres cromossômicos e de DNA mitocondrial. Master Thesis. Universidade Estadual Paulista, Botucatu, São Paulo, Brazil.

Andreata A.A., Almeida-Toledo L.F., Oliveira C. and Toledo-FIlHo S.A., 1994 - Cytogenetic studies on the subfamily Hypoptopomatinae (Pisces, Siluriformes, Loricariidae): III. Analysis of seven species. Caryologia, 47: 27-37.

ARMBRUSTER J.W., 2002 - Hypancistrus inspector: a new species of suckermouth armored catfish (Loricariidae: Ancistrinae). Copeia 2002: 86-92.

Armbruster J.W., Sabaj M.H., Hardman L.M., Page L.M. and Knouft J.H., 2000 - Catfish genus Corymbophanes (Loricariidae: Hypostominae) with description of one new species: Corymbophanes kaiei. Copeia 2000: 997-1006.

ARTONI R.F., 1996 - Estudos citogenéticos na família Loricariidae, com ênfase no gênero Hypostomus Lacépède (1803) (Pisces, Siluriformes). Master thesis. Universidade Federal de São Carlos, São Carlos, SP.

ARTONi R.F. and BERTOLlo L.A.C., 1996 - Cytogenetic studies on Hypostominae (Pisces, Siluriformes, Loricariidae). Considerations on karyotype evolution in the genus Hypostomus. Caryologia, 49: 81-90.

Carneiro A.S.P., Pauls E., Oliveira A.S.S., Silva L.P. and VIEIRA W.S., 1998 - Projeto Managé:
Estudos citogenéticos de Harttia sp. e Loricariichthys sp. (Pisces, Loricariidae) da bacia hidrográfica do rio Itabopoana (MG/ES/RJ). VII Simp. Citog. Evolut. Aplic. Peixes Neotrop., B11.

Della-Rosa V.A., Bertollo L.A.C., Ferrari I., Takarashi C.S., Moreira-Filho O. and FORESTI F., 1980 - Estudos citogenéticos em peixes da Amazônia. II. Ordem Siluriformes. Ciência e Cultura (suplemento), 32: 735.

DE PINNA M.C., 1998 - Phylogenetic relationships of Neotropical Siluriformes (Teleostei: Ostariophysi): bistorical overview and synthesis of hypotheses. In: Malabarba L.R., Reis R.E., Vari R.P., Lucena Z.M.S., Lucena C.A.S. (Eds.), "Phylogeny and Classification of Neotropical Fishes", pp. 279330. Edipucrs, Porto Alegre.

FenOCCHIO A.S., 1993 - Cromossomos supranumerários no gênero Rhamdia (Pisces). Caracterização cromossômica e considerações sobre a evolução cariotípica nos Siluroidei. PhD. Thesis. Faculdade de Medicina de Ribeirão Preto. Universidade de São Paulo.

FERRARIS C.J., 1998 - Catfishes and knifefishes. In: Paxton J.r., Eschmeyer W.N. (Eds.), "Encyclopedia of fishes", pp. 106-112. Academic Press, San Diego.

Foresti F., Almeida-Toledo L.F. and ToledoFILHO, S.A., 1981 - Polymorphic nature of nucleolus organizer regions in fishes. Cytogenet. Cell. Genet., 31: 137-144.

FoRESTI F., OLIVEIRA C. and AlMEIDA-TOLEDO L.F., 1993 - A method for chromosome preparations from large specimens of fishes using in vitro short treatment with colchicine. Experientia, 49: 810-813.

Giuliano-Caetano L., 1998 - Polimorfismo cromossômico Robertsoniano em populações de Rineloricaria latirostris (Pisces, Loricariinae). $\mathrm{PhD}$. Thesis. Departamento de Ciências Biológicas, Universidade Federal de São Carlos.

Giuliano-Caetano L., Moreira-Filho O. and BERTOLLO L.A., 1999 - Estudos citogenéticos em Rineloricaria pentamaculata (Langeani e Araujo, 1994). Genet. Mol. Biol., 22: 192.

GYLDENHOLM A.O. and SCHEEL J.J., 1971 - Chromosome numbers of fishes. I. J. Fish. Biol., 3: 479-486.

HowelL W.M. and BLACK D.A., 1980 - Controlled silver staining of Nucleolus Organizer Regions with a protective colloidal developer: a 1-step method. Experientia, 36: 1014-1015.

ISBRÜCKER I.J.H., 1980 - Classification and catalogue of the mailed Loricariidae (Pisces, Siluriformes). Versl. Techn. Gegevens, Univ. van Amsterdam, no. 2.

LARA M.C.S. and Júlio-Jr. H.F., 1994 - Análise cromossômica de duas espécies de Ancistrinae 
(Siluriformes, Loricariidae). V Simp. Citog. Aplic. Peixes Neotrop., p. 16.

Levan A., Fredga K. and SANDBERg A.A., 1964 Nomenclature for centromeric position on cbromosomes. Hereditas, 52: 201-220.

Michelle J.L., TAKAHASHI C.S. and FERRATI I., 1977 - Karyotypic study of some species of the family Loricariidae (Pisces). Cytologia, 42: 539 546.

NELSON J.S., 1994 - Fishes of the world. John Wiley \& Sons, Inc., New York, USA.

Oliveira C. and GoszTONyi A.E., 2000 - A cytogenetic study of Diplomystes mesembrinus (Teleostei, Siluriformes, Diplomystidae) with a discussion of chromosome evolution in siluriformes. Caryologia, 53: 31-37.

Oliveira A.S.S., Souto P.S.S., Pauls E. and Matos E., 1998 - Estudos citogenéticos em Loricaria sp. (Pisces, Loricariidae) rio Jari, município de Almeirim, estado do Pará. XXII Congres. Brasil. Zool., p. 222.

Roncati H.A., Corio C., Malone G., Fenocchio A.S. and PASTORI M.C., 1999 - Relevamiento citogenetico en peces del rio Paraná (Argentina).
VII Subfamílias Loricariinae e Hypostominae (Pisces, Siluriformes, Loricariidae). Genet. Mol. Biol., 22: 82.

SCAVONE M.D.P., 1993 - Análise citogenética de espécies dos gêneros Loricaria e Loricariichthys (Loricariidae, Siluriformes) da bacia do rio Paraná. Master Thesis. Universidade Estadual de Maringá.

SCAVONE M.D.P. and Júlio-JR. H.F., 1995 - Cytogenetics analysis and heterochromatin distribution in ZZ/ZW Sex chromosomes of the mailed catfish Loricariichthys platymetopon (Loricariidae: Siluriformes). Rev. Brasil. Genet., 18:31-35.

SCHAEFER S.A., 1987 - Osteology of Hypostomus plecostomus (Linnaeus) with a phylogenetic analysis of the loricariid subfamilies (Pisces: Siluroidei). Contributions in Science, Natural History Museum of Los Angeles County, 394: 1-31.

TCHAICKA L. and MARGARIDO V.P., 1999 - Descrição do cariótipo de Ancistrus sp. (Pisces, Loricariidae, Ancistrinae) coletado no rio Alto Alegre, bacia do rio Iguaçú. Genet. Mol. Biol., 22: 22.

Received June 6, 2002; accepted August 28, 2002 